\title{
Air Leakage Analysis of Research Reactor HANARO Building in Typhoon Condition for the Nuclear Emergency Preparedness
}

\author{
Goanyup Lee*, Haecho Lee, Bongseok Kim, Jongsoo Kim, Pyungkyu Choi \\ Department of Emergency Preparedness, Korea Atomic Energy Research Institute, Daejeon, Korea
}

\section{Original Research}

Received July 17, 2015

Revision September 28, 2016

Accepted September 30, 2016

Corresponding author: Goanyup Lee

Korea Atomic Energy Research Institute, 111 Deadeok-daero 989 beon-gil, Yuseong-gu, Daejeon 34057, Korea Tel: $+82-42-868-8813$

Fax: +82-42-868-2336

E-mail: gylee@kaeri.re.kr

This is an Open-Access article distributed under the terms of the Creative Commons Attribution NonCommercial License (http://creativecommons.org/ licenses/by-nc/4.0) which permits unrestricted noncommercial use, distribution, and reproduction in any medium, provided the original work is properly cited.

Copyright $\odot$ 2016 The Korean Association for Radiation Protection

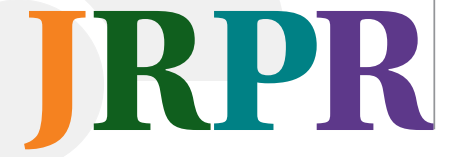

Background: To find out the leak characteristic of research reactor 'HANARO' building in a typhoon condition

Materials and Methods: MELCOR code which normally is used to simulate severe accident behavior in a nuclear power plant was used to simulate the leak rate of air and fission products from reactor hall after the shutdown of the ventilation system of HANARO reactor building. For the simulation, HANARO building was designed by MELCOR code and typhoon condition passed through Daejeon in 2012 was applied.

Results and Discussion: It was found that the leak rate is $0.1 \% \cdot$ day $^{-1}$ of air, $0.004 \% \cdot$ day $^{-1}$ of noble gas and $3.7 \times 10^{-5} \% \cdot$ day $^{-1}$ of aerosol during typhoon passing. The air leak rate of $0.1 \% \cdot d a y^{-1}$ can be converted into $1.36 \mathrm{~m}^{3} \cdot \mathrm{hr}^{-1}$, but the design leak rate in HANARO safety analysis report was considered as $600 \mathrm{~m}^{3} \cdot \mathrm{hr}^{-1}$ under the condition of $20 \mathrm{~m} \cdot \mathrm{sec}^{-1}$ wind speed outside of the building by typhoon.

Conclusion: Most of fission products during the maximum hypothesis accident at HANARO reactor will be contained in the reactor hall, so the direct radiation by remained fission products in the reactor hall will be the most important factor in designing emergency preparedness for HANARO reactor.

Keywords: Nuclear emergency, Leak rate, Source-term, Nuclear facility, Nuclear research reactor, Confinement building

\section{Introduction}

A Maximum Hypothesis Accident (MHA) in the nuclear research reactor HANARO is the fuel damage by a flow channel blockage and the release of radioactive materials by the design leak rate of the reactor building. The design leak rate of the HANARO reactor building was confirmed by the pressure differential experiments in 1995. In these experiments, the positive pressure was derived by air supply to the building, and the pressure drop and duration were measured, and the leak rate was then calculated by the equation described in the document of American National Standards Institute (ANSI) [1]. The range of leak rate measured for 10 times in 1995 was $405-546 \mathrm{~m}^{3} \cdot \mathrm{hr}^{-1}$ in the pressure differential $25 \mathrm{mmWG}$ and $37-45 \mathrm{~m}^{3} \cdot \mathrm{hr}^{-1}$ in the pressure differential 1.54 mmWG [2]. However, the positive pressure is not caused in the reactor building by a fuel channel blockage accident because the HANARO research reactor is operated at 
about $40^{\circ} \mathrm{C}$ in the pool temperature under normal air pressure and the loss of the reactor pool water does not occur in the MHA. Thus, only the pressure differential can be derived by the high wind outside of the building. According to the equation, the $25 \mathrm{mmWG}$ pressure differential between the inner and outer walls can be derived by a $20 \mathrm{~m} \cdot \mathrm{sec}^{-1}$ wind speed in the outside of the building, the $1.54 \mathrm{mmWG}$ pressure differential can be derived by a $5 \mathrm{~m} \cdot \mathrm{sec}^{-1}$ wind speed outside of the building. Thus, HANARO considered a design leak rate of $600 \mathrm{~m}^{3} \cdot \mathrm{hr}^{-1}$ derived in the condition of maximum wind speed, $20 \mathrm{~m} \cdot \mathrm{sec}^{-1}$, observed in the Daejeon area where HANARO is located. But this application has some problems. The positive pressure in a building makes the air in the building flow into every direction for releasing to the outside of the building. This means the pressure differential between the inner and outer walls by positive pressure in a building influences every walls of the building. But the pressure differential by a high wind speed outside of the building affects only the parts of the building over the ground, and the air inside the building can be flowed through leak points over the ground of the building, and also positive or negative pressure in a wall can be changed because the wind direction will be changed. This means air can be flowed to the inside from the outside of the building or to the outside from the inside of the building by the change in wind direction. Based on the review mentioned above, the air leak rate of the HANARO building under a typhoon condition was reviewed using the MELCOR code by applying the methodology suggested by the United States Department of Energy [3].

Table 1. HANARO Control Volume (CV) Information Designed for MELCOR Calculation

\begin{tabular}{lrrl}
\hline CV No. & Elevation $(\mathrm{m})$ & Volume $\left(\mathrm{m}^{3}\right)$ & \multicolumn{1}{c}{ Description } \\
\hline 100 & 0.0 & 0.0 & Reactor hall \\
& 5.0 & $5,780.5$ & \\
& 13.4 & $14,586.7$ & \\
200 & 27.8 & $34,737.6$ & \\
& 5.0 & 0.0 & Truck access area \\
& 13.4 & 904.8 & \\
300 & 0.0 & & \\
& 27.0 & $12,074.4$ & \\
400 & 0.0 & 0.0 & Technical gallery to connect \\
& 2.5 & 1,875 & secondary cooling system \\
600 & 5.0 & 0.0 & Outside of truck access area \\
& 27.8 & $1.0 \mathrm{E} 10$ & \\
700 & 0.0 & 5.0 & Outside of HVAC room \\
& 27.8 & $1.0 \mathrm{E} 10$ & \\
900 & 76.0 & 0.0 & Outside over the stack \\
& 100.0 & $1.0 \mathrm{E} 11$ & \\
\hline
\end{tabular}

\section{Materials and Methods}

\section{MELCOR computer code input design}

The MELCOR computer code was used to calculate the leak rate of the HANARO reactor building under typhoon conditions. The following points are considered for calculation.

First, the building structure, such as the section plans and side views in the design documents, was analyzed to make the MELCOR input file about the building structure. The MELCOR input file about the HANARO building structure, which is called the Control Volume, was designed as shown in Table 1 and Figure 1.

Second, the pressure differential effect due to wind was designed by using the following equation:

$$
\Delta \mathrm{P}=\mathrm{c}_{p} \rho \frac{v^{2}}{2}
$$

Where $c_{p}$ is pressure coefficient, $\rho$ is local air density, $v$ is wind speed.

The values of the pressure coefficient, which was used in the determination of HNANRO building design leak rate were chosen [2]. The values are as follows:

- Upwind pressure coefficient: 0.8

- Downwind pressure coefficient: -0.5

- Side and top pressure coefficient: -0.7

Third, the air flow paths such as penetration, access doors, and duct of the HVAC system of the building were analyzed. The determined flow path based on the building structure analysis is shown in Table 2 . The ratio in the Table 2 shows the relative size of flow paths, and the size was calculated

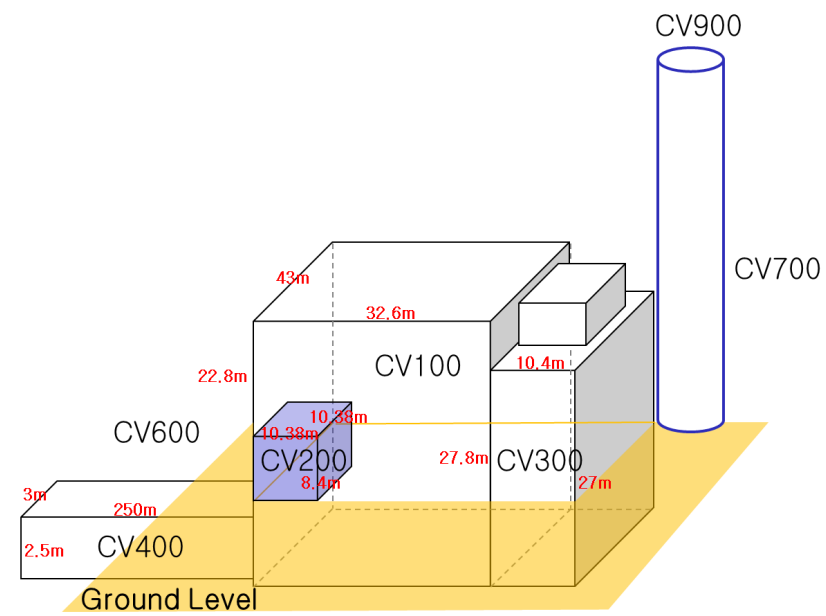

Fig. 1. HANARO building structure and control volume for MELCOR input. 
Table 2. Flow Path for MELCOR Calculation and Leak Ratio to Fit the Real Test Leak Rate in HANARO Building

\begin{tabular}{|c|c|c|c|c|}
\hline $\begin{array}{l}\text { Flow } \\
\text { path }\end{array}$ & $\begin{array}{l}\text { Number of } \\
\text { connected } \\
\text { control } \\
\text { volume }\end{array}$ & $\begin{array}{l}\text { Elevation } \\
\text { (m) }\end{array}$ & Description & $\begin{array}{l}\text { Ratio } \\
(\%)\end{array}$ \\
\hline FL110 & $100-200$ & $13.40-13.37$ & $\begin{array}{l}\text { Flow path from 3rd floor of } \\
\text { reactor hall to the truck } \\
\text { access area }\end{array}$ & 62.72 \\
\hline FL120 & $100-200$ & $4.97-5.00$ & $\begin{array}{l}\text { Flow path from basement } \\
\text { floor of reactor hall to the } \\
\text { truck access area }\end{array}$ & 26.88 \\
\hline FL130 & $100-300$ & $13.40-13.40$ & $\begin{array}{l}\text { Flow path from reactor hall to } \\
\text { the east side office building } \\
\text { through door gap }\end{array}$ & 0.8 \\
\hline FL140 & $100-400$ & $1.00-1.00$ & $\begin{array}{l}\text { Flow path from reactor hall to } \\
\text { the west side technical gal- } \\
\text { lery penetration }\end{array}$ & 1.1 \\
\hline FL210 & $100-700$ & $27.50-27.50$ & $\begin{array}{c}\text { Flow path from reactor hall to } \\
\text { the east side exhaust duct }\end{array}$ & 4.25 \\
\hline FL220 & $100-900$ & $27.50-76.00$ & $\begin{array}{l}\text { Flow path from reactor hall to } \\
\text { the stack }\end{array}$ & 4.25 \\
\hline FL310 & $200-600$ & 7.00-7.00 & $\begin{array}{l}\text { Flow path from truck access } \\
\text { area to the west side envi- } \\
\text { ronment }\end{array}$ & 89.6 \\
\hline
\end{tabular}

based on the design drawing of HANARO structure. This table shows that the truck access area is the major leak point.

Fourth, the area of the flow path was defined. The leak rate under the condition of positive pressure in the reactor hall had been tested regularly. The leak rate in $25 \mathrm{mmWG}$ positive pressure during reactor hall temperature $22^{\circ} \mathrm{C}$ was recently measured as about $486 \mathrm{~m}^{3} \cdot \mathrm{hr}^{-1}$ by HANARO operating department. ${ }^{1}$ However, the design leak rate in $25 \mathrm{mmWG}$ positive pressure was determined as $600 \mathrm{~m}^{3} \cdot \mathrm{hr}^{-1}$. The determined flow path was adjusted to meet the design leak rate by using following equation and leak ratio.

$$
\text { Hydraulic_Diameter }=\frac{(4 \times \text { Flow_Area })}{(\text { Wetted_Perimeter })}
$$

The air leak rate in the $25 \mathrm{mmWG}$ positive pressure in the reactor hall after the leak area correction was calculated as shown in Figure 2. The calculated results correspond to the design leak rate of the HANARO building.

Fifth, $1 \mathrm{~kg}$ noble gas and $1 \mathrm{~kg}$ aerosol diffusion condition during 1 hour was applied to simulate an accident condition.

\section{Design of typhoon condition}

A typhoon passed through the Korean Peninsula two times in August of 2012. At that time, the wind speed and di-

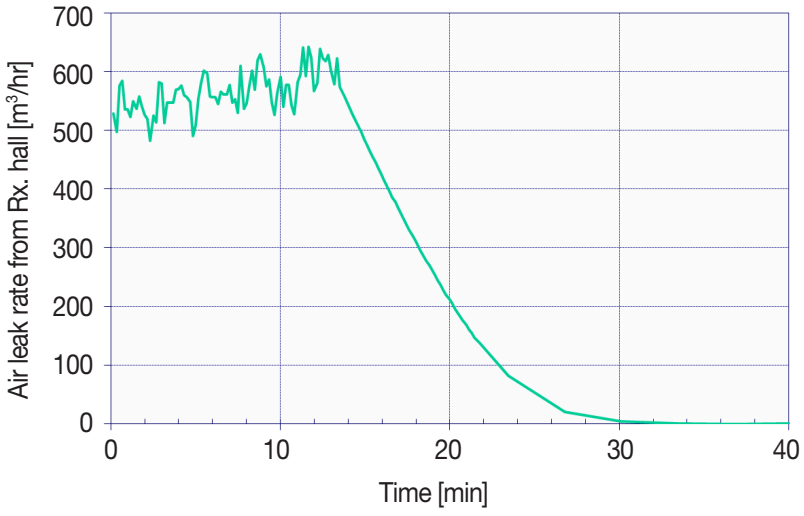

Fig. 2. Air leak rate simulated from reactor hall in $25 \mathrm{mmWG}$ positive pressure.

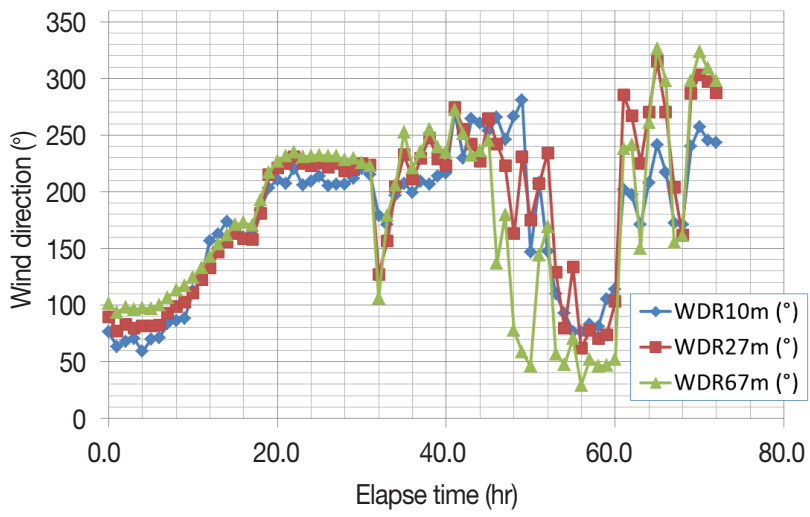

Fig. 3. Wind direction change measured while the typhoon passed at KAERI site.

rection were measured at $10 \mathrm{~m}, 27 \mathrm{~m}$, and $67 \mathrm{~m}$ heights of the meteorological tower at the Korea Atomic Energy Research Institute (KAERI) site. A momentary high wind speed more than $20 \mathrm{~m} \cdot \mathrm{sec}^{-1}$ at a $67 \mathrm{~m}$ height was measured 11 times on August 28 in 2012, and the average wind speed for 10 minutes at the time was about $15 \mathrm{~m} \cdot \mathrm{sec}^{-1}$. Even though the high wind was not sustained for enough time, the metrological data measured on August 2012 reflects the actual high wind speed condition by typhoon at KAERI site. The wind speed, $20 \mathrm{~m} \cdot \mathrm{sec}^{-1}$, was the wind condition considered to calculate the design leak rate in the HANARO building.

Also the wind direction is a very important factor from the point of view of negative pressure occurring at outside of the building by a high wind speed. The wind direction observed in 2012 is shown in Figure 3.

The MELCOR input file to apply the typhoon condition in 2012 was generated using Equation 1. The wind speed and

1) Test Results according to the Reactor Hall Leak Test Procedures (HANTAP-05-OD-ROP-SI-53, Rev.5) by Choi Yeongsan in 2012;8-11. 
Table 3. Absolute Pressure Outside of the Building Derived from the Typhoon Condition

\begin{tabular}{llcc}
\hline \multirow{2}{*}{ Time (sec) } & \multicolumn{3}{c}{ Absolute pressure (Pa) } \\
\cline { 2 - 4 } & $\begin{array}{c}\text { Outside of truck } \\
\text { access area }\end{array}$ & $\begin{array}{c}\text { Outside of pent } \\
\text { house }\end{array}$ & Over stack \\
\hline 0.0 & 101349.245 & 101370.5273 & 101325.1393 \\
3600 & 101346.5118 & 101377.4388 & 101316.0253 \\
7200 & 101348.4638 & 101371.3512 & 101324.0359 \\
10800 & 101347.9875 & 101372.1331 & 101321.6197 \\
14400 & 101342.189 & 101394.1478 & 101293.4238 \\
18000 & 101341.3678 & 101396.0378 & 101290.4896 \\
& \multicolumn{3}{c}{ Intermediate omission } \\
331200 & 101352.9004 & 101350.5806 & 101347.7844 \\
334800 & 101352.9002 & 101351.9924 & 101350.1259 \\
338400 & 101352.9002 & 101352.7115 & 101351.9168 \\
342000 & 101352.9002 & 101352.8892 & 101352.773 \\
345600 & 101352.5522 & 101357.3652 & 101344.7688 \\
\hline
\end{tabular}

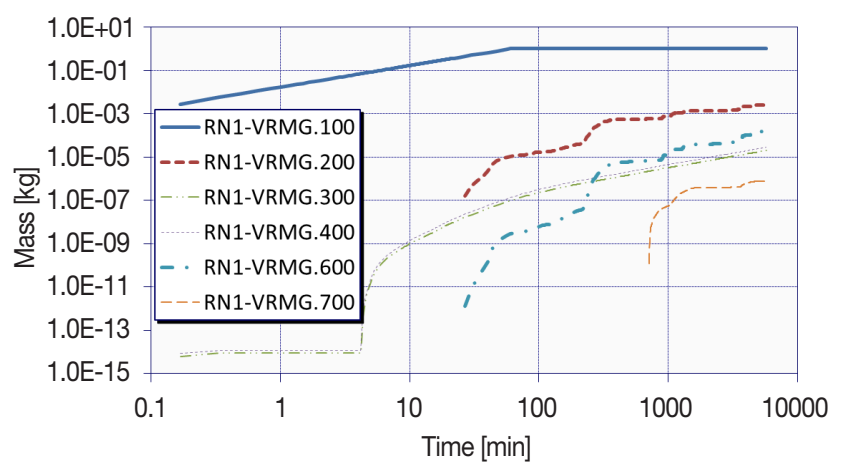

Fig. 4. Noble gas distribution in each control volume by time after accident.

direction for the MELCOR calculation were as shown in Table 3 .

\section{Results and Discussion}

\section{Radioactive material leak rate under typhoon conditions}

The change of noble gas distribution by a typhoon after an accident in each Control Volume was analyzed, and the results are described in Figure 4. In this figure, the RN1-VRMG.100 means the amount of noble gas in Control Volume 100 which is the reactor hall and RN1-VRMG. 600, 700, 900 mean the amounts of noble gas in a Control Volume of 600 , 700, 900 respectively. The Control Volumes of 600, 700, and 900 mean the outside of the building. The calculation results show that most of the noble gas remained in the reactor hall and some noble gas was released to the outside of the building. The total amount of noble gas released to the environ-

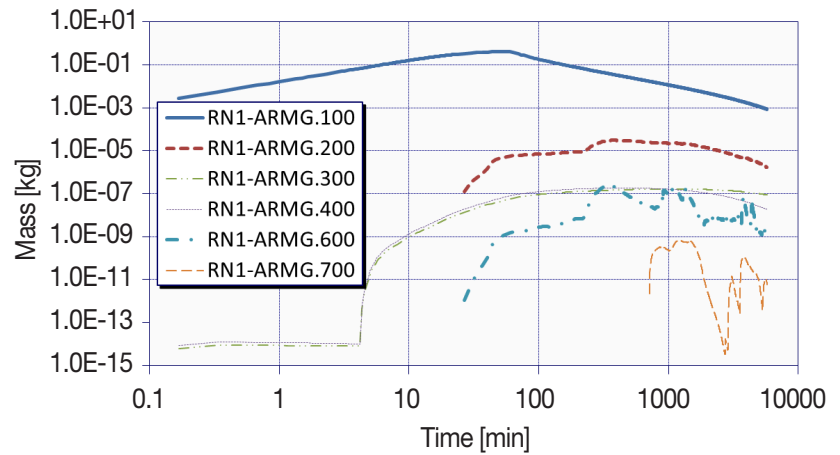

Fig. 5. Aerosol distribution in air in each control volume by time after accident.

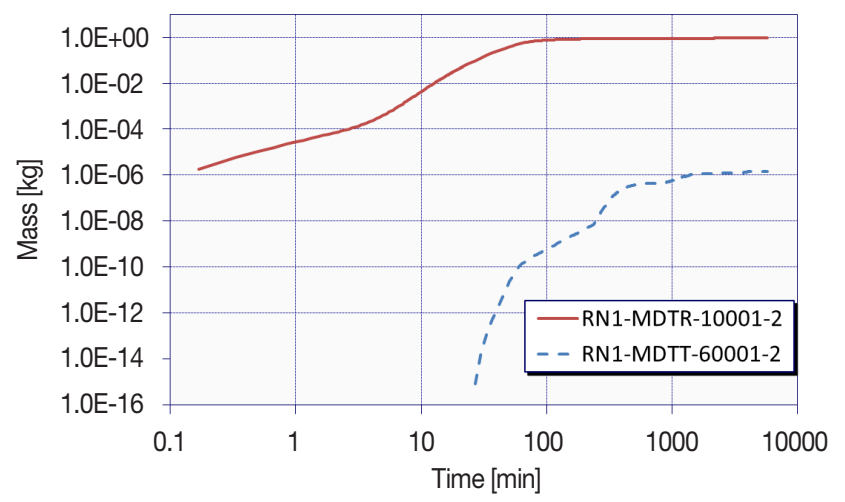

Fig. 6. Aerosol distribution in the floor in each control volume by time after accident.

ment for 4 days was $1.559722 \times 10^{-4} \mathrm{~kg}$, and it can be changed to $1.5597 \times 10^{-2} \% \cdot 4$ days $^{-1}$ or $0.004 \%$.day ${ }^{-1}$ leak rate.

The changes of aerosol distribution in each Control Volume in air is shown in Figure 5 and on the floor of reactor hall and outside are shown in Figure 6. The amount of aerosol in the reactor hall was calculated as $0.9064003 \mathrm{~kg}$ that is $90.64 \%$. The total amount of aerosol released into the environment for 4 days was $1.474 \times 10^{-4} \%$, and it can be converted to $3.7 \times 10^{-5} \%$.day ${ }^{-1}$. Almost all of the noble gases and aerosols will remain in the reactor hall in case of fuel damage by a channel blockage accident because the accident does not make a high pressure in the HANARO reactor hall.

\section{Air leak rate in typhoon condition}

Even though there is a typhoon in the outside of the building, air in the reactor hall does not flow to only one direction after the HVAC system shutdown. The typhoon makes the wind direction change while passing an area because the typhoon rotates. Thus, the typhoon creates a positive pressure differential or negative pressure differential against one side 


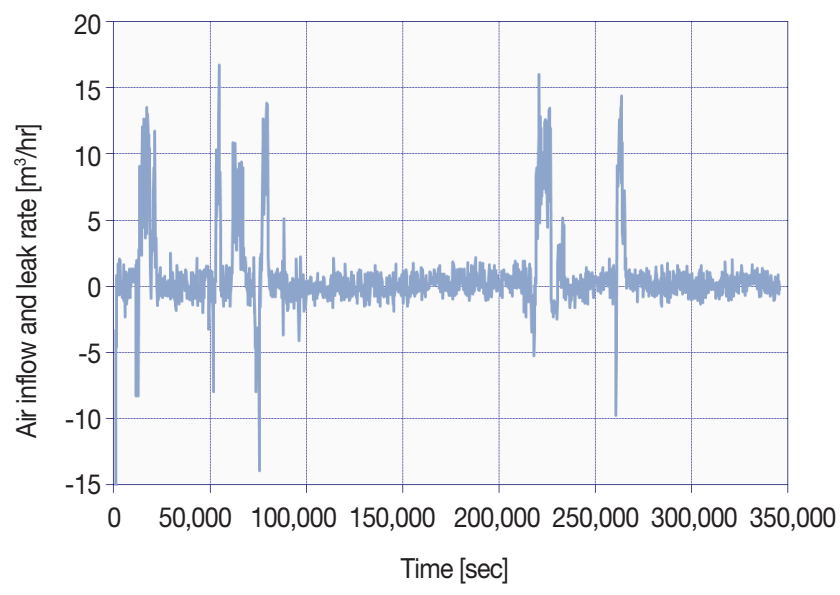

Fig. 7. Air inflow and leak rate against reactor building while the typhoon passed.

of a building in one area while passing. The simulated result of the air flow in the HANARO building while the typhoon passed in August 2012 is shown in Figure 7. The total air amount flowing into the reactor hall for 4 days was $76.2 \mathrm{~m}^{3}$, and the air amount leaked into the environment during 4 days was $130.79 \mathrm{~m}^{3}$. The air leak rate was $0.376 \% \cdot 4$ days $^{-1}$, it can be converted into $0.094 \% \cdot$ day $^{-1}$. Thus, the air leak rate of the HANARO building can be defined as $0.1 \% \cdot$ day $^{-1}$ for the typhoon condition.

\section{Conclusion}

The leak characteristic under typhoon conditions was simulated using the MELCOR computer code. The leaked air amount was $0.4 \% .4$ days $^{-1}$ of the reactor hall volume, and the leaked noble gas amount was $0.016 \% \cdot 4$ days $^{-1}$ of the total noble gas in the reactor hall, and the leaked aerosol amount was $1.47 \times 10^{-4} \% \cdot 4$ days $^{-1}$ of the total aerosol in the reactor hall. The design air leak rate considered in the safety analysis reports was $600 \mathrm{~m}^{3} \cdot \mathrm{hr}^{-1}$ under a $20 \mathrm{~m} \cdot \mathrm{sec}^{-1}$ wind speed condition, which can derive $25 \mathrm{mmWG}$ pressure deferential be- tween each sides of a wall, in the outside of the building and also the air leak rate recently measured in $25 \mathrm{mmWG}$ positive pressure in reactor hall was about $486 \mathrm{~m}^{3} \cdot \mathrm{hr}^{-1}$, but the simulated air leak rate in a real typhoon condition was $0.1 \% \cdot$ day $^{-1}$, which means $1.36 \mathrm{~m}^{3} \cdot \mathrm{hr}^{-1}$. It shows that there was some misunderstanding in the assume of safety analysis, that is, first, the positive pressure inside building cannot be continued more than several minutes because air leak will make a negative pressure inside a building, second, the wind outside a building has a direction, it means that air will flow to outside or inside of a building depending on the geometrical structure of the building.

It can be found from this simulation that the design air leak rate is too high compared to the simulated result. If the leak rate is less than past consideration, the emergency preparedness should be changed. The direct radiation from the reactor hall will be more important detriment in emergency preparedness because almost all of the radioactive materials will be in the space of the reactor hall after releasing from reactor core to reactor hall because of low leak rate.

\section{Acknowledgements}

This is the result of the project of emergency preparedness for nuclear research facilities in KAERI.

\section{References}

1. American National Standards Institute. Containment system leakage testing requirements. ANSI/ANS-56.8. 1981;14.

2. Korea Atomic Energy Research Institute. Leak rate criteria and test result for KMRR confinement. KM-210-RT-K076. 1995;1215.

3. United Sates Department of Energy. MELCOR computer code application guidance for leak path factor in documented safety analysis. Final report. 2004;26-31. 